\title{
ANALISIS DAMPAK PENETEPAN UU NO.28/2009 TERHADAP ABNORMAL RETURN DAN TRADING VOLUME ACTIVITY (STUDI KASUS PADA PERUSAHAAN ROKOK DI BEI)
}

\author{
Nurfauziah \\ Rossy Afiano \\ Universitas Islam Indonesia
}

\begin{abstract}
ABSTRACK
This study aims to analyze the differences in the average abnormal return and the average trading volume activity on tobacco companies on the Stock Exchange before and after the promulgation of Law No.28/2009 events. This study uses event study, which carried out observations of the average abnormal return and the average trading volume activity for 5 days before and 5 days after the event. Results of this study indicate there are differences in the average abnormal return and the average trading volume but no significant activity before and after the promulgation of Law No.28/2009 events, suggesting that market participants had anticipated with no rush to transactions, average abnormal return obtained is negative which means that the information content of the event is bad information. The average trading volume greater activity in the period before the event was announced this suggests that investors anticipate likely done in the period before the event announced.

Keywords: abnormal return, trading volume activtiy, event study
\end{abstract}

\footnotetext{
PENDAHULUAN

Pada tanggal 18 Agustus 2009, DPR mengesahkan UU No.28/2009 tentang pajak daerah dan retribusi daerah. Di dalam UU tersebut terdapat aturan mengenai pengenaan pajak rokok baru. Hal ini menjadi informasi tersendiri bagi para pelaku industri rokok, tak terkecuali bagi para investor yang memiliki saham di perusahaan rokok yang terdaftar di pasar modal Indonesia. Informasi yang terkandung dari peristiwa itu dapat mempengaruhi fluktuasi harga dan volume perdagangan. Suryawijaya dkk (1998) menyatakan bahwa peristiwa yang berkaitan dengan lingkungan ekonomi makro seperti perubahan bunga, kurs valuta asing, serta
}

berbagai regulasi dan deregulasi ekonomi yang dikeluarkan oleh pemerintah turut berpengaruh pada fluktuasi harga dan volume perdagangan di pasar modal.

Informasi yang ada sangat mempengaruhi tingkat kepekaan pasar modal terhadap harga saham dan volume perdagangan saham yang akan memberikan dampak terhadap return saham yang diperoleh. Investor mendasari keputusan investasinya pada informasi yang dimiliki, baik itu informasi yang tersedia di publik maupun informasi pribadi. Sebuah informasi akan memiliki nilai jika informasi tersebut mampu membuat investor bereaksi dengan melakukan transaksi di pasar modal, jika pengumuman penetapan perundangan oleh pemerintah memiliki kandungan informasi yang cukup, 
maka penetapan itu akan dapat mempengaruhi preferensi investor dalam keputusan investasinya.

Pengaruh penetapan perundangan dapat dianalisis dengan menggunakan penelitian event study, dengan melihat perbedaan perubahan harga saham dan volume perdagangan pada saat sebelum pengumuman dan setelah pengumuman penetapan. Menurut Jogiyanto (2010) event study merupakan studi yang mempelajari reaksi pasar terhadap suatuperistiwa(event)yang informasinya dipublikasikan sebagai pengumuman. Event study dapat digunakan untuk menguji efisiensi pasar bentuk setengah kuat. Perubahan harga saham akan diukur dengan menggunakan return saham sebagai nilai perubahan harga dan abnormal return yang merupakan selisih antara return yang sesungguhnya terjadi dengan return yang diharapkan. Sementara perubahan volume perdagangan akan di ukur menggunakan trading volume activity (TVA). Penelitian ini akan berfokus pada masalah dampak penetapan UU No.28/2009 terhadap abnormal return dan TVA pada saham emiten rokok di BEI.

Tujuan dari penelitian ini adalah untuk mengetahui perbedaaan rata-rata abnormal return dan rata-rata trading volume activity antara sebelum dan sesudah pengumuman penetapan Undang-undang nomor 28 tahun 2009.

\section{REVIEW LITERATUR DAN HIPOTESIS}

Pengumuman penetapan UU No.28/2009 diduga mempunyai kandungan informasi yang bisa mempengaruhi reaksi pasar. Reaksi tersebut ditunjukkan dengan adanya abnormal return dan perubahan trading volume activity. Abnormal return adalah selisih antara return sesungguhnya dengan return ekspektasi (Jogiyanto, 2010). Formulasinya adalah sebagai berikut (Jogiyanto, 2010):

$$
\mathbf{A R i}, \mathbf{t}=\mathbf{R i}, \mathbf{t}-\mathbf{E}[\mathbf{R i}, \mathbf{t}]
$$

Keterangan:

ARi,t = abnormal return sekuritas ke-i pada periode peristiwa ke-t

$\mathrm{Ri}, \mathrm{t}=$ return sesungguhnya sekuritas ke-i pada periode peristiwa ke-t

$\mathrm{E}[\mathrm{Ri}, \mathrm{t}]=$ return ekspektasi sekuritas ke-i pada periode peristiwa ke-t

Sedangkan trading volume activity adalah ukuran perubahan aktivitas volume saham yang diperdagangkan. Hasil perhitungan trading volume activity mencerminkan antara jumlah saham yang diperdagangkan dengan jumlah saham yang beredar dalam periode tertentu. Formulasi TVA sebagai berikut (Foster, dalam Husnan dkk. 1996):

$\mathbf{T V A}=\frac{\sum \text { saham perusahaan i yang diperdagangkan pada waktu t }}{\text { Jumlah saham beredar perusahaan i pada waktu } \mathrm{t}}$

Menurut Peterson (1998), event study adalah suatu pengamatan mengenai harga saham di pasar modal untuk mengetahui apakah terdapat abnormal return yang diperoleh investor akibat dari suatu peristiwa tertentu. Sehingga teknik ini yang digunakan dalam penelitian ini.

Beberapa penelitian mengenai abnormal return dan TVA telah dilakukan, diantaranya dilakukan oleh Leung, et al (2005) yang meneliti tentang perbedaan abnormal return dan TVA di pasar modal hongkong dengan peristiwa pengumuman stock split, hasilnya terdapat perbedaan abnormal return yang signifikan pada saat sebelum dan sesudah stock split, juga terdapat perbedaan TVA yang signifikan pada saat sebelum dan sesudah pengumuman stock split. Kemudian perbedaan abnormal return dan TVA yang signifikan akibat suatu perstiwa juga dikemukakan oleh Nurhaeni (2009) yang meneliti perbedaan abnormal return dan TVA pada peristiwa pemilu legislatif Indonesia 2009. Peristiwa-peristiwa tersebut menunjukkan bahwa informasi yang dikandung kemudian direspon oleh investor. Berbeda dengan penelitian Munawaroh (2009) yang meneliti tentang 
pengaruh suspend BEI terhadap abnormal return dan TVA, hasilnya tidak ada perbedaan yang signifikan antara sebelum dan sesudah peristiwa, ini menunjukkan bahwa investor sudah melakukan langkah antisipasi terhadap persitiwa tersebut.

Berdasarkan research gap tersebut, maka peneliti melakukan penelitian terhadap pengaruh penetapan UU No.28/2009 terhadap abnormal return dan TVA dengan menggunakan teknik event study. Rumusan hipotesis sebagai berikut:

Hipotesis 1: Terdapat perbedaan rata-rata abnormal return pada perusahaan rokok di BEI sebelum dan sesudah pengumuman penetepan UU no.28/2009

Hipotesis 2: Terdapat perbedaan rata-rata trading volume activity pada perusahaan rokok di BEI sebelum dan sesudah pengumuman penetapan UU no. $28 / 2009$

\section{METODE PENELITIAN}

Jenis Data, Sumber Data, dan Objek Penelitian

Penelitian ini menggunakan data jenis sekunder, yaitu harga saham penutupan harian dan volume perdagangan saham harian perusahan sampel yang dijadikan objek penelitian. Data itu kemudian digunakan untuk menghitung abnormal return dan trading volume activity. Objek penelitian dari penelitian ini adalah perusahaan-perusahaan rokok yang terdaftar di BEI pada tahun 2009 yang terdiri dari PT Gudang Garam Tbk, PT HM Sampoerna Tbk, dan PT Bentoel International Investama Tbk. Perhitungan abnormal return dengan menggunakan indeks IHSG yang akan digunakan sebagai expected return. Data penelitian ini diperoleh dari Pojok Bursa Efek Indonesia Fakultas Ekonomi Universitas Islam Indonesia dan dari website BEI yaitu idx.co.id.

\section{Tahap Analisis Data}

Rumusan masalah yang dikemukakan pada penelitian ini dijawab dengan melakukan beberapa proses dalam menganalisis data. Pertama mengidentifikasi tanggal penetapan UU NO.28/2009 yaitu tanggal 18 Agustus 2009 yang kemudian dijadikan sebagai t0, kedua menentukan event window (periode pengamatan) yaitu dimulai dari 5 hari sebelum penetapan (t-5) dan 5 hari sesudah penetapan $(t+5)$, periode ini dipilih untuk mengamati reaksi pasar selama beberapa hari sebelum dan sesudah peristiwa penetapan UU No.28/2009 dan untuk menghindari lebih banyak peristiwa lain yang dapat turut mempengaruhi reaksi pasar. Jadi sebaiknya periode pengamatan yang ditetapkan tidak terlalu lama.

Langkah berikutnya adalah melakukan analisa deskriptif untuk menggambarkan kondisi yang terjadi selama periode pengamatan baik sebelum dan sesudah peristiwa penetapan UU No.28/2009. Langkah keempat melakukan uji beda paired sample t-test, sebelum dilakukan uji beda paired sample t-test terhadap rata-rata abnormal return dan TVA, maka dilakukan uji normalitas data dengan One-Sample Kolomogrov Smirnov Test karena syarat uji beda adalah data harus terdistribusi normal.

\section{HASIL PENELITIAN DAN PEMBAHASAN}

Tabel 1

Statistik Deskriptif Rata-rata Abnormal Return Saham Emiten Rokok

(Tanggal 10 sampai dengan 25 Agutus 2009)

\begin{tabular}{|c|c|c|c|c|c|}
\hline & D & Minimum & Maximum & Mean & Std. Deviation \\
\hline 10 Agustus (t-5) & 3 &,- 0372 &,- 0172 &,- 029533 &, 0107858 \\
11 Agustus (t-4) & 3 &,- 0076 &,- 0041 &,- 005267 &, 0020207 \\
12 Agustus (t-3) & 3 &, 0101 &, 0158 &, 013567 &, 0030436 \\
13 Agustus (t-2) & 3 &,- 0209 &, 0038 &,- 010733 &, 0129160 \\
14 Agustus (t-1) & 3 &,- 0658 &, 0141 &,- 015900 &, 0435087 \\
19 Agustus (t+1) & 3 &,- 0048 &, 0253 &, 011267 &, 0151527 \\
20 Agustus (t+2) & 3 &,- 0223 &,- 0085 &,- 015733 &, 0069241 \\
21 Agustus (t+3) & 3 &,- 0023 &, 0011 &,- 001167 &, 0019630 \\
24 Agustus (t+4) & 3 &,- 0248 &,- 0180 &,- 020267 &, 0039260 \\
25 Agustus (t+5) & 3 &,- 0078 &,- 0020 &,- 005067 &, 0029143 \\
Valid N (listwise) & 3 & & & & \\
\hline
\end{tabular}

Sumber: data diolah,2013 
Tabel 1 di atas menunjukkan bahwa rata-rata abnormal return harian selama periode pengamatan sebagian besar bernilai negatif. Pada 10 hari periode pengamatan sebelum dan sesudah, hanya ada dua hari yang bernilai positif, ini menunjukkan bahwa informasi yang terkandung dalam peristiwa penetapan UU No.28/2009 adalah informasi yang buruk ( $b a d$ news). Investor menerima informasi tersebut sebagai sinyal buruk sehingga melakukan tindakan antisipasi dengan menjual saham yang dimilikinya.

\section{Tabel 2}

Statistik Deskriptif Rata-rata Trading Volume Activity Saham Emiten Rokok

(Tanggal 10 sampai dengan 25 Agutus 2009)

\begin{tabular}{|c|c|c|c|c|c|}
\hline & D & Minimum & Maximum & Mean & Std. Deviation \\
\hline 10 Agustus (t-5) & 3 &, 0000180 &, 0001100 &, 000065333 &, 0000460579 \\
11 Agustus (t-4) & 3 &, 0000160 &, 0000650 &, 000038333 &, 0000247857 \\
12 Agustus (t-3) & 3 &, 0000130 &, 0000790 &, 000038333 &, 0000355715 \\
13 Agustus (t-2) & 3 & $2 \mathrm{E}-7$ &, 0000150 &, 000010067 &, 0000085448 \\
14 Agustus (t-1) & 3 &, 0000090 &, 0000360 &, 000020667 &, 0000138684 \\
19 Agustus (t1) & 3 & $0 \mathrm{E}-7$ &, 0000490 &, 000025667 &, 0000245832 \\
20 Agustus (t2) & 3 & $7 \mathrm{E}-7$ &, 0000320 &, 000018567 &, 0000161141 \\
21 Agustus (t3) & 3 & $0 \mathrm{E}-7$ &, 0000680 &, 000029000 &, 0000350856 \\
24 Agustus (t4) & 3 & $0 \mathrm{E}-7$ &, 0000390 &, 000015667 &, 0000205994 \\
25 Agustus (t5) & 3 & $0 \mathrm{E}-7$ &, 0000150 &, 000007333 &, 0000075056 \\
Valid N (listwise) & 3 & & & & \\
\hline
\end{tabular}

Sumber: data diolah, 2013

Pada tabel 2 di atas dapat dilihat bahwa rata-rata trading volume activity harian banyak yang lebih besar pada periode pengamatan sebelum peristiwa penetapan UU No.28/2009 diumumkan, ini mengindikasikan bahwa informasi buruk yang terkandung dalam peristiwa tersebut diantisipasi oleh investor dengan melakukan transaksi sebelum peristiwa terjadi.

Transaksi banyak dilakukan dari periode $\mathrm{t}-5$, $\mathrm{t}-4$, dan $\mathrm{t}-3$. Selanjutnya volume perdagangan mengalami pergerakan berfluktuasi tetapi tidak berbeda jauh. Hal ini menandakan bahwa investor tidak terburu-buru mengambil keputusan bertransaksi.

Setelah melakukan analisa deskriptif terhadap abnormal return dan TVA, kemudian dilakukan uji beda paired sample t-test.
Tabel 3

Uji Beda Rata-rata Abnormal Return 5 Hari Sebelum dan 5 Hari Setelah Penetapan UU No.28/2009

\begin{tabular}{|l|c|c|}
\hline & $\begin{array}{c}\text { Rata-rata Abnormal } \\
\text { Return Saham Emiten } \\
\text { Rokok di BEI Sebelum } \\
\text { Penetapan UU No. } \\
28 / 2009\end{array}$ & $\begin{array}{c}\text { Rata-rata Abnormal } \\
\text { Return Saham Emiten } \\
\text { Rokok di BEI Sesudah } \\
\text { Penetapan UU No. } \\
28 / 2009\end{array}$ \\
\hline Mean & $-0,009567$ & $-0,0062$ \\
\hline $\begin{array}{l}\text { Standar } \\
\text { deviasi }\end{array}$ & 0,0096257 & 0,0023 \\
\hline t & \multicolumn{2}{|c|}{$-0,492$} \\
\hline Sig. (2 tailed) & \multicolumn{2}{|c|}{0,672} \\
\hline keterangan & \multicolumn{2}{|c|}{ Tidak Signifikan } \\
\hline
\end{tabular}

Sumber: Data Sekumder yang diolah (2013)

Tabel 3 merupakan hasil perhitungan uji beda terhadap rata-rata abnormal return sebelum dan sesudah peristiwa, dari hasil uji beda tersebut menunjukkan bahwa rata-rata abnormal return sesudah peristiwa penetapan UU No.28/2009 lebih besar dibanding dengan sebelum peristiwa penetapan UU No.28/2009. Hal ini menunjukkan bahwa investor mengalami abnormal return negatif atau rugi yang lebih besar selama periode sebelum peristiwa. Namun dari sigfnikansi yang bernilai 0,672 di atas tingkat signifikansi yang ditetapkan yaitu $5 \%$ atau 0,005 , maka disimpulkan tidak terdapat perbedaan abnormal return yang signifikan dari peristiwa penetapan UU No.28/2009 atau hipotesis pertama ditolak. Tidak adanya perbedaan abnormal return yang signifikan mengindikasikan para investor telah melakukan langkah antisipasi dengan tidak terburu-buru melakukan transaksi jual. Jika dilakukan dengan terburu-buru, maka akan memperbesar kemungkinan para investor mengalami kerugian yang lebih besar akibat dari informasi buruk yang terkandung dalam peristiwa penetapan UU No.28/2009. 
Tabel 4

Uji Beda Rata-rata Trading Volume Activity 5 Hari Sebelum dan 5 Hari Setelah Penetapan UU No. 28/2009

\begin{tabular}{|c|c|c|}
\hline & $\begin{array}{c}\text { Rata-rata Trading } \\
\text { Volume Activity } \\
\text { Saham Emiten Rokok } \\
\text { di BEI Sebelum } \\
\text { Penetapan UU No. } \\
28 / 2009\end{array}$ & $\begin{array}{c}\text { Rata-rata Trading } \\
\text { Volume Activity } \\
\text { Saham Emiten Rokok } \\
\text { di BEI Sesudah } \\
\text { Penetapan UU No. } \\
28 / 2009\end{array}$ \\
\hline Mean & 0,000034667 & 0,000019367 \\
\hline Standar deviasi & 0,00001747 & 0,00001945 \\
\hline t & \multicolumn{2}{|c|}{0,784} \\
\hline Sig. (2 tailed) & \multicolumn{2}{|c|}{ Tidak Signifikan } \\
\hline keterangan & \multicolumn{2}{|c|}{} \\
\hline
\end{tabular}

Sumber: Data Sekumder yang diolah (2013)

Tabel 4 menunjukkan bahwa rata-rata TVA lebih besar pada periode sebelum peristiwa penetapan UU No.28/2009, ini menunjukkan bahwa langkah antisipasi yang dilakukan investor banyak dilakukan sebelum peristiwa terjadi. Hal ini sejalan dengan penemuan rata-rata abnormal return negatif yang membuat investor merugi lebih besar pada periode pengamatan sebelum peristiwa. Rata-rata TVA yang lebih besar tentu juga berpengaruh pada nilai abnormal return yang diperoleh investor.

Hasil perhitungan uji beda menunjukkan tingkat signifikansi 0,515 diatas tingkat signifikansi yang ditetapkan sebesar 5\% atau 0,05 , maka disimpulkan tidak terdapat perbedaan rata-rata TVA yang signifikan atau hipotesis kedua ditolak. Tidak adanya perbedaan TVA yang signifikan mengindikasikan bahwa investor melakukan transaksi sebagai tindakan antisipasi dengan tidak terburu-buru.

\section{KESIMPULAN DAN SARAN}

Kesimpulan dari penelitian ini adalah tidak terdapat perbedaan rata-rata abnormal return dan rata-rata trading volume activity yang signifikan, hal ini karena investor sudah melakukan tindakan antisipasi terhadap informasi buruk yang terkandung dalam persitiwa penetapan UU No.28/2009 yang di dalamnya memuat pengenaan pajak rokok yang baru. Langkah antisipasi dalam melakukan transaksi juga dilakukan dengan tidak terburu-buru. Rata-rata abnormal return sebelum dan sesudah peristiwa yang bernilai negatif menunjukkan bahwa informasi yang terkandung dalam peristiwa itu adalah informasi yang buruk (bad news), dan langkah antisipasi cenderung dilakukan pada periode sebelum peristiwa penetapan UU No.28/2009 yang ditunjukkan oleh volume transaksi yang lebih besar.

Penelitian ini tidak luput dari sejumlah keterbatasan, yaitu terdapat hari libur nasional 17 Agustus pada periode pengamatan sebelum peristiwa yang mungkin saja dapat mempengaruhi harga dan aktivitas perdagangan saham, juga karena tahun 2009 merupakan tahun politik dimana saat itu berlangsung pemilu legislatif yang dapat juga mempengaruhi harga dan aktivitas perdagangan saham. Implikasi dari penelitian ini, informasi yang relevan memang sangat diperlukan bagi para investor guna sebagai bahan pertimbangan melakukan investasi, sehingga investor perlu dengan cermat dan pandai memilah mana informasi yang benar-benar berguna dan mana yang tidak, penulis berharap penelitian ini dapat menjadi sebuah informasi yang relevan bagi investor guna dijadikan bahan pertimbangan jika kelak terjadi peristiwa yang berkaitan dengan regulasi yang dikeluarkan pemerintah.

\section{DAFTAR PUSTAKA}

Hartono, J. (2010), Teori Portofolio dan Analisis Portofolio, Edisi ketujuh, Yogyakarta: BPFE

Husnan, S. (1998), Dasar-dasar Teori Portofolio dan Analisis Investasi,UUP, Yogyakarta: AMP YKPN

Leung, Tak Yan, et al. (2005), Do Stock Splits Really Signal?, pp. 1-33 
Munawaroh. (2009), Analisis Perbandingan Abnormal Return dan Tradning Volume Activity Sebelum dan Sesudah Suspend BEI (Studi Kasus pada Saham LQ-45 di BEI Periode 6-15 Oktober 2008), Tesis Magister manajemen, Semarang: Program Pascasarjana Universitas Diponegoro

Nurhaeni, N. (2009), Dampak Pemilihan Umum Legislatif Indonesia Tahun 2009 terhadap Abnormal Return dan Aktivitas Volume Perdagangan Saham di BEI (Uji Kasus pada Saham yang Terdaftar Dalam Kelompok Perusahaan LQ-45), Tesis Magister manajemen, Semarang: Program Pascasarjana Universitas Diponegoro
Peterson, Pamela P. (1989), Event Studies: A Review of Issues and Methodology, Quarterly Journal of Business and Economics, Summer, Vol. 28, No. 3. H. 33-66.

Suryawijaya, Asri Marwan, dan Setiawan Faizal Arief. (1998). Reaksi Pasar Modal Indonesia Terhadap Peristiwa Politik Dalam Negeri (Event Study pada Peristiwa 27 Juli 1996), kelola No. 28. 